\title{
ИНТЕРТЕКСТУАЛЬНОСТЬ
}

\author{
Г.А. Иоакимиди
}

\section{ДИСКУРС ШОУ-БИЗНЕСА КАК СПЕЦИФИЧЕСКАЯ СФЕРА АНГЛОЯЗЫЧНОГО ДИСКУРСИВНОГО ПРОСТРАНСТВА}

Аннотация. Предметом исследования является анализ основных черт дискурса шоу-бизнеса как специфической сфреры англоязычного дискурсивного пространства. Объектом исследования являются дискурсивные фрагменты современного английского языка из сферы шоу-бизнеса. Автор подробно рассматривает данную сферу, которая, как представляется, характеризуется наличием особого вида дискурса с определёнными характеристиками, присущими только ему. Особое внимание уделяется анализу понятия «дискурс» и его характерных черт - системообразующих признаков - применительно к сфере шоу-бизнеса. Дискурс сферы шоу-бизнеса представляет собой одновременно особый когнитивно-коммуникативный процесс, непосредственно связанный с созданием множества речевых произведений в сфере шоу-бизнеса, и определённую совокупность текстов (как устных, так и письменных), получаемых в результате данного процесса, посвящённых событиям, происходящим в сфере шоубизнеса в совокупности с интралингвистическими и экстралингвистическими факторами.

В рамках исследования применяется комплексный метод исследования, который включает в себя методы дискурсивного и контекстуального типов анализа, метод сплошной выборки дискурсивных фрагментов. Автор приходит к выводу о правомерности выделения дискурса шоу-бизнеса как специфической сферы англоязычного дискурсивного пространства. Данный вид дискурса обладает всеми системообразующими признаками: имеет своих участников, цели, стратегии и тактики коммуникации, хронотоп, тематику коммуникации, базовые ценности, разновидности и жанры дискурса, прецедентные тексты, дискурсивные формулы, а также функции, реализуемые в рамках дискурсивного процесса.

Ключевые слова: дискурс, шоу-бизнес, дискурсивное пространство, коммуникация, знаменитость, дискурсанализ, институциональный дискурс, шоу, хронотоп, адресат.

Abstract. The subject of the research is the analysis of the main features of show business discourse as a specific sphere of the English-language discursive space. The object of the research is the discursive elements of contemporary English used in the sphere of show business. The author examines this sphere as having a special type of discourse with particular characteristics. Special attention is paid to the analysis of the definition of 'discourse' and its characteristics, i.e. systemically important features, in the sphere of show business. Show business discourse is viewed both as a cognitive communication process that directly relates to the creation of numerous verbal pieces in the sphere of show business and a certain combination of texts, both oral and written, created as a result of the aforesaid process and devoted to the events ongoing in the sphere of show business combined with intra-linguistic and extra-linguistic factors. Within the framework of the present research, the author has applied the integrated research method that combined discursive and contextual analysis methods as well as the method of continuous sampling of discursive elements. The author concludes that it is appropriate to talk about show business discourse as a specific sphere of the English-language discursive space. The discourse of this kind has all th systemically important elements, in particular, it implies participants, goals, strategies and communication techniques, chronotope, communication topics, basic values, kinds and genres of discourse, precedent texts, discursive formulas and finally functions to be fulfilled as part of the discursive process.

Key words: chronotope, discourse, discourse analysis, institutional discourse, show, celebrity, communication, discursive space, audience, show business.

И зучение дискурса сферы шоу-бизнеса является весьма актуальным в связи с повсеместной коммерциализацией индустрии развлечений. Последняя включает как музыкальную эстраду в целом, так и смежные виды человеческой деятельности, в частности, киноиндустрию, массовые спортивные состязания, различные развлекательные телепередачи, кон- 
курсы красоты, музыкальное телерадиовещание, рекламу и т.д. Сфера шоу-бизнеса, как представляется, характеризуется наличием особого вида дискурса с определёнными характеристиками, присущими только ему [ср.: 1-12].

Прежде всего, следует отметить отсутствие единой трактовки понятия «дискурс» в современной лингвистике в целом. Одни из первых упоминаний о дискурсе (дискурс-анализе) можно найти в работах 3. Харриса, который писал о «методе анализа связанной речи», в рамках которого учитывается соотношение языка и культуры [13, с. 355-383], т.е. происходит учёт интралингвистических и экстралингвистических параметров. Подобного мнения придерживались такие учёные, как Дж. Граймс, Р. Ленекер, Т. Гивон, У. Чейф и др. С точки зрения весьма популярного во второй половине XX в. семиотического подхода дискурс рассматривается как определённым образом упорядоченная материальная, не имеющая фиксированных границ, незамкнутая и незавершённая система знаков, находящихся в некоторых отношении друг с другом [14; 15$]$.

По мнению М. Фуко, дискурс - это «совокупность множества разнообразных сфер человеческого познания, множество высказываний, принадлежащих одной формации» [16, с. 170]. В данном случае подчёркивается не только и не столько знаковая природа дискурса, рассматриваемого как совокупность знаков, используемых для обозначения различных предметов, процессов, явлений, но и тот факт, что дискурс является частью структуры, сегментом человеческого знания и одновременно соответствующей дискурсивной практикой [16]. Придерживаясь приведённой точки зрения и развивая идеи М. Фуко, В.Е. Чернявская подразумевает под дискурсом «особые языковые формации, коррелирующие с той или иной областью общественной практики, человеческого познания и коммуникации» $[17$, с. 74]. Как видим, в данном определении подчеркивается когнитивная составляющая дискурса.

Функциональный подход к дискурсу предполагает рассмотрение данного феномена одновременно как в качестве процесса речевой деятельности и смыслотворчества, так и в качестве её результата, т.е. текста. По мнению многих учёных, дискурс - это более широкое понятие, чем текст, это функционирование языка вживую, в реальном времени [18, с. $308 ; 19$, с. $243-281 ; 20 ; 21$, с. 59 и др.].

Структурно-синтаксический подход к рассмотрению дискурса находит отражение, в частности, в определении В.А. Звегинцева: дискурс представляет собой «...два или несколько предложений, находящихся в смысловой связи...» между собой [22, c. 17]. Одной из современных и актуальных точек зрения является позиция В.Г. Борботько, в рамках которой дискурс расценивается как относительно самостоятельная языковая единица высшего порядка, в отличие от языковых единиц низшего порядка (например, фонем, морфем и т.д.), не обладающая полной или частичной регулярной воспроизводимостью в языке. По мнению исследователя, дискурс - это единица, принадлежащая к высшему уровню языка, которая состоит из связанных по смыслу предложений и напрямую создаётся в речи [23, с. 30-31]. Учёный также подчёркивает наличие у дискурса языковой и этноязыковой, жанровой специфики, лингвостилистических и лингвокультурных особенностей, а также различий в употреблении дискурсивных моделей в разных лингвокультурах [23].

Т.А. ван Дейк под дискурсом понимает «коммуникативное событие», сложное единство языковой формы, значения и действий, регулируемых параметрами прагматических макростратегий [24, c. 46]. Таким образом, по мнению учёного, под дискурсом понимается текст с включением социального коммуникативного контекста. В данном случае важными характеристиками дискурса являются его материальность, функциональность, а также событийность. При этом социальный коммуникативный контекст характеризует как участников коммуникации, так и процессы порождения и восприятия речи с учётом фоновых знаний коммуникантов.

По мнению Ж. Куртэ, дискурс представляет собой многокомпонентное целое, которое создаётся множеством специально отобранных и сочетающихся определённым способом языковых единиц, служащих в качестве строительного материала для «речевых актов, являющихся актами коммуникации, <...> как частей определённой глобальной целостности» $[25$, с. 28]. Как мы видим, в данном определении подчёркивается факт построения более крупных единиц из более мелких: языковые единицы - речевые акты (акты коммуникации) сложное коммуникативное целое.

Интересной представляется точка зрения П. Шародо, который под дискурсом понимает совокупность «высказывания» и «коммуникативной ситуации» [26, с. 28], «воплощение, наглядное изображение другой речи»; «...неповторимый, единичный результат процесса, зависящего от говорящего и от условий речепроизводства» [26, с. 69]. Учёный отмечает, что полученный текст пересекается со множеством дискурсов, описывающих какую-либо ситуацию и принадлежащих к какому-либо жанру.

Подобная точка зрения, свойственная иностранным учёным, присутствует и у некоторых отечественных учёных-дискурсологов - Н.Д. Арутюновой, Ю.Н. Караулова, В.В. Петрова, В.И. Карасика, 
М.Б. Шинкаренковой и др. Наиболее популярным является определение дискурса, данное Н.Д.Арутюновой: дискурс - это «речь, погружённая в жизнь», «текст, взятый в событийном аспекте» [27, c. 136-137]. Похожее, несколько более развёрнутое описание того, что такое дискурс, дают Ю.Н. Караулов и В.В. Петров: дискурс - это «сложное коммуникативное явление, включающее кроме текста, ещё и экстралингвистические факторы (знания о мире, мнения, установки, цели адресата), прагматические, социокультурные, психологические и другие факторы, необходимые для понимания текста» [28, c. 8]. Таким образом, получается, что дискурс - это совокупность текста(ов) и ситуации их создания и актуализации.

В современных исследованиях, посвящённых дискурс-анализу, под дискурсом понимается некоторая совокупность текста и контекста, включающего интралингвистическую и экстралингвистическую составляющие части [см. напр.: 29, с. 19]. Таким образом, вслед за многими лингвистами [16; $24 ; 27 ; 28 ; 30 ; 31 ; 32$ и др.], мы разграничиваем понятия дискурса и текста как процесс и результат соответственно, подчёркивая значительно больший объём понятия дискурса в связи с включением экстралингвистической, социокультурной, прагматической и других видов информации.

По мнению В.И. Карасика, дискурс - это «текст, погружённый в ситуацию общения», допускающий «множество измерений» и взаимодополняющих подходов в изучении, в том числе структурно-лингвистический, лингвокультурный, психолингвистический, прагмалингвистический, социолингвистический [33, с. 5-6].

С когнитивной точки зрения, нам важно определение Е.С. Кубряковой и О.В. Александровой, которые рассматривают дискурс как особого рода когнитивный процесс, связанный с производством речи, созданием некоего речевого произведения, при этом конечным результатом процесса речевой деятельности, имеющим определённую законченную и зафиксированную форму, является текст [34, c. 186-197].

С точки зрения социолингвистики, различают персональный (индивидуальный) и институциональный виды дискурса [33; 35 и др.]. Традиционно под институциональным дискурсом понимается особый тип дискурса, «осуществляемый в общественных институтах, общение в которых является неотъемлемой частью их организации» [35, с. 42]. По мнению Е.И. Шейгал, данный тип дискурса характеризуется ограниченной тематикой общения, специфическим набором интенций и типичных речевых событий для данной сферы, речевыми стратегиями и тактиками, обусловленными интенциональной составляющей, а также особыми представлениями о типичных моделях речевого поведения при исполнении определённых социальных ролей.

Весьма значительное разнообразие сфер человеческой деятельности предполагает также существование множества различных крупных и менее масштабных видов и разновидностей дискурса, например: бытовой, общественно-политический, дискурс СМИ, научный, медицинский, педагогический, рекламный, религиозный, спортивный, экономический, юридический и т.д. Если приведённые виды дискурса получили освещение в лингвистической литературе в той или иной степени, то некоторые новые виды дискурса ещё не выделялись в качестве объекта исследования. В частности, одним из подобных новых видов/разновидностей дискурса, выделяемых в соответствии с определёнными чисто лингвистическими и экстралингвистическими параметрами и характеристиками, является дискурс сферы шоу-бизнеса.

Проанализировав существующие точки зрения на сущность дискурса, мы приходим к следующему определению данного понятия применительно к сфере шоу-бизнеса: дискурс сферы шоу-бизнеса представляет собой одновременно особый когнитивно-коммуникативный процесс, непосредственно связанный с созданием множества речевых произведений в сфере шоу-бизнеса, и определённую совокупность текстов (какустных, так и письменных), получаемых в результате данного процесса, посвящённых событиям, происходящим в сфере шоу-бизнеса в совокупности с интралингвистическими и экстралингвистическими (лингвокультурными, психолингвистическими, прагмалингвистическими, социолингвистическими, ситуативными и т.д.) факторами.

В шоу-бизнесе, подобно политике, борьба за зрителя/читателя носит острый конкурентный характер: выигрывает тот, у кого больше экономических, информационных, творческих и других ресурсов.

Современный шоу-бизнес не может успешно развиваться без таких средств и источников влияния, как средства массовой информации (СМИ) и реклама. Роль последних в процессе популяризации шоу-бизнеса неоценима, СМИ и реклама напрямую участвуют в процессе формирования общественного сознания благодаря оперативности предоставления информации, доступности, широкому охвату аудитории, многоплановости, социальной ориентированности [см.: 36, с. 152-153] и т.д. Кроме того, важной составляющей развития шоу-бизнеса является пиар (PR), основополагающей целью которого является формирование ситуации успеха организации или объекта PR в обществе, формирование эффективной системы коммуникаций социального объекта (известной лич- 


\section{Интертекстуальность}

ности) с общественностью, создание его позитивного имиджа в обществе [37-41 и др.].

Мы живём в эпоху глобализации, в мире, в котором происходит непрерывное расширение политического и социокультурного пространства, подчинённого воздействию данных властных ресурсов. Данное влияние, будь оно положительное или отрицательное, отражается в соответствующем типе дискурса. В рамках СМИ, рекламы и пиара сегодня оттачиваются эффективные способы информирования аудитории, создания определённого имиджа и репутации шоуменов, воздействия на зрителей/читателей посредством дискурса сферы шоу-бизнеса.

В настоящее время дискурс сферы шоу-бизнеса проникает во все сферы человеческой жизни. В целом, наряду с некоторыми другими учёными-лингвистами [см, в частности, 42; 43], мы считаем, что нарастает тенденция повседневной и повсеместной «шоуизации» общества. Последняя подразумевает стремление власти, правительства вызвать в обществе чувство хронического переживания праздника, стремление развлекать и отвлекать от какихлибо общественно-политических и экономических проблем, имеющих место быть в стране. Не секрет, что для того чтобы почувствовать себя полноценным, человек должен всё время изменяться любыми средствами, развиваться, в его жизни постоянно должно что-то происходить. В современной нестабильной реальности, кризисе идентичности, повсеместной массовой культуре, потере связей и отношений между людьми возникает девиз «Жизнь как шоу», который помогает людям приспособиться к меняющимся условиям и даёт возможность жить дальше. В целом, в настоящее время происходит «шоуизация» мировосприятия зрителя - массового обывателя: СМИ на многих каналах сосредоточились на звёздах, «селебрити», вовлекая общественное сознание в праздность как всеми одобряемую и разделяемую ценность и норму.

Среди основных характеристик дискурса сферы шоу-бизнеса необходимо отметить его зрелищность, презентационность, массовость и интерактивный (диалогический) характер. Кроме того, в связи с участием в различных шоу знаменитостей - звёзд разной величины из сфер кино, телевидения, музыки, а также в контексте культивирования у зрителей практически слепого поклонения перед обладателями звания «звезды», можно говорить о «звёздном» характере дискурса. Любое шоу призвано заинтересовать, развлечь и вовлечь зрителя, а значит, дискурс сферы шоу-бизнеса обладает такими свойствами, как гедонистичность, или ориентация на получение удовольствия, карнавальность, или наличие празднично-карнавальной культуры у самого шоу и его участников, иллюзионистичность, или изображение действительности, основанное на обмане чувств зрителей, на создании иллюзии, видимости красивой жизни, причастности к шоу, вовлечения в действие вследствие особого психического состояния во время просмотра. Каждое шоу подразумевает заказ на получение удовольствия особого рода (например, эстетического, бесцельно-праздного), что и находит отражение в соответствующем лексиконе, употребляемом, прежде всего, молодёжью: awesome, cool, wicked, sound, class, quality, boss, bad, sweet, mint, sick, amazin', crackin', dope (амер.) (круто, отлично, круто, классно, первоклассный, замечательный, великолепный, самый лучший, превосходный, крутой, чумовой, безбашенный, прикольный) [44].

Дискурс сферы шоу-бизнеса имеет манипулятивный характер и обладает маркетинговой прагматичностью, т.е. с его помощью можно определённым образом манипулировать людьми, навязывать им определённое мнение с целью получения максимальной прибыли [см.: 45-49 и др.].

Дискурс - понятие неоднородное, многомерное, включающее как текстовую составляющую, так и ряд экстралингвистических, социокультурных и психологических факторов, о чём уже было сказано выше. С функциональной точки зрения, дискурс - это открытая, иерархически упорядоченная система знаков. Как известно, исследование любого типа дискурса невозможно без рассмотрения его структуры.

Представляется интересной концепция М.Б. Шинкаренковой, которая выделяет три уровня в дискурсе рок-поэзии: 1) внешний уровень, включающий визуальный (обложки альбомов, логотипы, рекламные плакаты концертов, презентаций альбомов) и вербальный (названия фестивалей, рок-коллективов, альбомов и текстов) ряды; 2) основной уровень, включающий синтез «звучащей» поэзии, рок-композиций, театрального шоу; 3) ядерный уровень, содержащий совокупность поэтических текстов рок-авторов [29, с. 22-33]. Аналогичным образом в рамках дискурса сферы шоу-бизнеса можно выделить внешний уровень с визуальным (обложки музыкальных альбомов, дисков с фильмами, рекламные плакаты концертов и т.д.) и вербальным (название ТВ-шоу, фестивалей, концертов, коллективов, альбомов и текстов) рядами; основной уровень, подразумевающий синтез звучащей речи шоуменов, ведущих, звёзд в рамках выступлений и интервью; и ядерный уровень, включающий совокупность текстов, имеющих непосредственное отношение к сфере шоу-бизнеса.

По мнению В.И. Карасика, институциональные типы дискурса имеют сложную структуру, в которую входят несколько компонентов: участни- 
ки, хронотоп, цели, ценности, стратегии, материал (тематика), разновидности и жанры, прецедентные тексты, дискурсивные формулы [31, с. 266]. В рамках нашего исследования англоязычного дискурса сферы шоу-бизнеса данная структура, предложенная В.И. Карасиком, представляется весьма актуальной, т.к. она наиболее полно отражает основные характеристики, присущие дискурсу как феномену.

Следует отметить, что дискурс сферы шоу-бизнеса пересекается с бытовым дискурсом, что проявляется в использовании разговорной, повседневной формы речи, употреблении всех форм речи литературного и нелитературного языка (терминов, просторечия, профессионального сленга, профессионализмов и т.д.) [50, с. 35]. При этом в рамках англоязычного дискурса сферы шоу-бизнеса используется как диалогическая, так и монологическая речь.

В настоящей статье нас интересует, прежде всего, вербальный уровень дискурса сферы шоу-бизнеca, а именно: тексты, заголовки статей, рекламных объявлений о концертах и шоу, интервью знаменитостей, звезд эстрады и т.д., тексты, связанные с событиями и фигурами сферы шоу-бизнеса, а также речевые формулы дискурса сферы шоу-бизнеса, т.е. определённые обороты речи, свойственные коммуникации в соответствующем социальном институте [31, с. 280]. Данный уровень определяет основные модели и сценарии развития концептуальной метафоры, её типовые прагматические смыслы в анализируемом дискурсе, общую метафорическую картину мира шоу-бизнеса [50, с. 35]. При этом дискурс сферы шоу-бизнеса, как представляется, подобно любому институциональному дискурсу, существует одновременно в нескольких плоскостях, которые между собой взаимодействуют, зачастую пересекаясь, объединяются в общее пространство: коммуникативное событие, идеологию, особый ментальный мир.

Как уже было сказано выше, существуют различные виды дискурса, которые формируются благодаря определённым системообразующим признакам. Совокупность данных признаков позволяет вычленить определённый дискурс из ряда существующих видов и разновидностей. В рамках статьи нас также интересуют критерии выделения дискурса сферы шоу-бизнеса современного английского языка в отдельный вид дискурса.

Вслед за В.И. Карасиком, к системообразующим признакам дискурса сферы шоу-бизнеса мы относим участников, цели, стратегии и тактики коммуникации, хронотоп, материал (тематику) коммуникации, базовые ценности, разновидности и жанры дискурса, прецедентные тексты, а также дискурсивные формулы. Кроме того, мы считаем необходимым добавить в данный список системо- образующих признаков функции, реализуемые в рамках дискурсивного процесса.

Рассмотрим подробнее каждый из перечисленных системообразующих признаков.

Одним из основных признаков является наличие определённых участников дискурса - представителей той или иной социальной группы, вступающих в коммуникативный процесс и исполняющих в его рамках определённые коммуникативные роли. Разновидности коммуникативных ролей напрямую зависят от вида дискурса. Так, например, в англоязычном дискурсе сферы шоу-бизнеса нами выявлено, по крайней мере, три разновидности коммуникативной роли:

- адресант (говорящий) - участник коммуникации, который согласно своему волеизъявлению направляет речь к тому или иному коммуниканту (Yeah. I go to Malawi twice a year. It's where two of my children were adopted from, and $\mathbf{I}$ have a lot of projects there that I go and check up on and children who I look after. (Madonna) [51]);

- прямой адресат (слушающий) - коммуникант в дискурсе шоу-бизнеса, на которого направлена речь, который может реально участвовать в разговоре (прямая коммуникация) или подразумеваться (опосредованная коммуникация), как например, в случае с ТВ-шоу, радиопередачами и т.д. (What you have to go through to release a film is probably the most arduous set of tasks - compared to all the other things an artist can release, it's probably the most labor-intensive, especially if you don't have any money and not a large team. (Terence Nance) [52]);

- адресат-наблюдатель (зрители, народ) - третий субъект дискурса шоу-бизнеса. Внимания этого обобщённого коммуниканта добиваются шоумены, известные личности, звезды, они ссылаются на интересы зрителей, и, как им кажется, представляют их мнение (We are very proud of that. The people that criticize our people are people who never read the Enquirer, don't understand the Enquirer and don't want to. (Iain Calder) [53]).

Под целью дискурса понимается предполагаемый результат коммуникации, обусловленный причинами конструирования и реализации дискурса.

Сущность и цели шоу-бизнеса как «коммерческой деятельности в сфере индустрии развлечений» [54] заложены в сознание участников коммуникации, а значит, отражены и в дискурсе сферы шоу-бизнеса. Следовательно, основным системообразующим критерием для выделения этого вида дискурса может служить тематический определитель цели - борьба за популярность, борьба за зрителей/читателей, получение максимальной при- 


\section{Интертекстуальность}

были на развлечениях. Цель дискурса шоу-бизнеса заключается в том, чтобы сформировать у адресата определённый стиль жизни - гламурный, свойственный известным личностям. Кроме того, целью также является привлечение внимания адресата к знаменитости - актёру, певцу, балерине, спортсмену и т.д., к специфической коллективной общности поп-группе, вокально-танцевальному коллективу, ансамблю, спортивной команде и т.д.

Следует отметить, что дискурс сферы шоу-бизнеса имеет собственную тематику (материал) коммуникации, которую также следует отнести к системообразующим факторам. Здесь для нас становится первостепенным тот факт, что дискурс может рассматриваться как система традиционных средств выражения той или иной темы. Среди основных тем дискурса сферы шоу-бизнеса можно назвать, в частности, следующие: жизнь звёзд, знаменитостей, их работа, достижения, карьера, личная жизнь, неудачи; события в мире моды, музыки, кино и телевидения и т.д.

Говоря о хронотопе как о категории времени и пространства, выступающей системообразующим фактором дискурса, мы отмечаем, что дискурс сферы шоу-бизнеса характеризуется более или менее определёнными пространственно-временными рамками. Кроме того, если рассматривать хронотоп как некоторую характерную коммуникативную ситуацию, повторяющуюся в определённом времени и месте [55], мы отмечаем наличие более дробных единиц, например, хронотопа интервью знаменитостей.

Хронотоп имеет существенное жанровое значение. Можно прямо сказать, что жанр и жанровые разновидности дискурса (как системообразующие факторы) определяются именно хронотопом [56], хронотоп как формально-содержательная категория в значительной мере определяет образ человека (знаменитости, «селебрити») в шоу-бизнесе; этот образ всегда хронотопичен. Не секрет, что каждый тип дискурса обладает своим, только ему присущим набором жанров. Среди жанров и жанровых разновидностей дискурса шоу-бизнеса мы отмечаем, например, следующие: памфлет, фельетон, проблемная аналитическая статья, написанная журналистом, репортаж, информационная заметка, рецензия и т.д. Базируясь на классификации шоу в рамках общего дискурса сферы шоу-бизнеса мы выделяем более частные виды дискурса, а именно:

дискурс интеллектуального шоу («The Weakest Link», «Wheel of Fortune» и др.);

дискурс презентационного шоу (открытие супермаркета, выставки, фестиваля, выход в свет новой книги, кинофильма, презентация научного проекта/доклада с последующим обсуждением и т.д.); дискурс телевизионного ток-шоу («The Jerry Springer Show» и т.п.);

дискурс «шоу со звездами» («Strictly Come Dancing» и т.п.);

- дискурс реалити-шоу («Big Brother», «Survivor» и т.п.);

- дискурс креативной командной игры («stand-up comedy», шоу типа «Comedy Club», межвузовские и межфакультетские турниры и т.п.);

дискурс тематического конкурсного шоу («Miss World», «Miss Universe», «Miss International Beauty», «Hell's Kitchen», «Eurovision» и т.п.);

- дискурс модельного шоу («New Hollywood Look», «Fashion Week» и т.п.);

- дискурс карнавала (новогодний карнавал, балкарнавал и т.п.);

- дискурс спортивного шоу («Intervilles», «Fort Boyard», открытие и закрытие Олимпийских игр и т.д.) и т.д.

Далее необходимо рассмотреть способы общения, а именно - избираемые участниками дискурса шоу-бизнеса специфические стратегии и такти$\kappa и$. Под коммуникативной стратегией понимается план оптимальной реализации коммуникативных намерений, продуманных говорящим/пишущим поэтапных речевых действий; линия речевого поведения, принятая на основе осознания коммуникативной ситуации в целом и направленная на достижение конечной коммуникативной цели (или целей) в процессе речевого общения. В рамках стратегии учитываются объективные и субъективные факторы и условия, в которых протекает акт коммуникации и которые в свою очередь обусловливают структуру текста [57, с. 22; 58, с. 6 и др.].

Каждая речевая (коммуникативная) стратегия реализуется благодаря использованию определённого набора тактик. Речевая (коммуникативная) тактика- это конкретный этап реализации коммуникативной стратегии, определяемый интенцией говорящего, эксплицированной совокупностью приёмов, обусловливающих применение языковых средств. Тактика - это речевой ход, соответствующий тому или иному этапу в реализации речевой стратегии и направленный на решение частной коммуникативной задачи этого этапа. Совокупность речевых тактик составляет речевую стратегию, а реализация последней направлена на достижение общей коммуникативной цели [57, с. 22; 58, с. 6 и др.].

В рамках дискурса сферы шоу-бизнеса наличие адресата-наблюдателя предопределяет возможность «игры на зрителя», т.е. стремление говорящего сделать процесс коммуникации более зрелищным, вызвать эмоциональный отклик/реакцию у аудитории (feedback). Очевидно стремление вовлечь в процесс коммуникации адресата-наблюда- 
теля, воспринимающего новости и события шоубизнеса как некое специально разыгрываемое для него действо, включить его в процесс «игры» (см. выше о процессе «шоуизации» общества).

В целом, в дискурсе сферы шоу-бизнеса формируются четыре стратегии [59]:

1) стратегия на понижение (анализ-«минус», тактика-обвинения, тактика безличного обвинения, тактика обличения, тактика оскорбления, тактика угрозы);

2) стратегия на повышение (анализ-«плюс», тактика презентации, тактика отвода критики, тактика неявной самопрезентации, тактика самооправдания);

3) стратегия театральности (тактика информирования, тактика кооперации, тактика обещания, тактика побуждения, тактика предупреждения, тактика прогнозирования, тактика размежевания, тактика провокации);

4) стратегия обобщения (тактика сближения).

Стратегия на понижение направлена на развенчание прежних идеалов и ценностей адресата (зрителей/читателей) путём занижения его самооценки. В результате данного процесса адресат становится более восприимчивым к тем ценностям, которые предлагают или навязывают представители шоу-бизнеса, ведущие шоу, известные личности, знаменитости. Например:

Cruise got into a heated discussion about Scientology in a now famous interview with Matt Lauer. "Scientology is something that you don't understand", he told Lauer, who had asked Cruise if he could ever be with someone who wasn't a Scientologist [60].

Примерами тактик оскорбления и угрозы, являющихся частью стратегии на понижение, могут послужить следующие дискурсивные фрагменты из сферы шоу-бизнеса (интервью участников ТВ-шоу):

'I'm a Celebrity' Willie: 'Antony and Dougie are $f^{* * * i n g ~ t h i e v e s ' . ~ W i l l i e ~ C a r s o n ~ c a l l s ~ A n t o n y ~ C o t t o n ~ a n d ~}$ Dougie Poynter "f***ing thieves" after they steal his towels.

However, the ex-jockey maintained: "He's lucky I didn't pull him out of the bed last night, I was very close to it. What you are doing to all the kids in England is condoning stealing. You don't steal, you don't lie, even in a game show. It is selfishness and I can't condone it" [61].

Стратегия обобщения направлена на создание иллюзии сближения участников дискурса сферы шоубизнеса (представителей шоу-бизнеса и зрителей, читателей). Данная стратегия зачастую реализуется посредством употребления местоимений (we, us и т.д.) и сравнительных конструкций с like, например:

Celebrities are like ordinary people. They need to maintain their figures just like anyone else, and there is more pressure on their part since they are constantly in the public eye. Ordinary people can have bodies of celebrities such as, too, and by following these diet and fitness plans, they can also look like red-carpet worthy [62].

Young actor JC DeVera is ecstatic because of the extra paycheck he got from TV5. According to John Estrada, another Kapatid, TV5 artists received one month bonus each. So that's the reason why JC is jumping for joy. Yes, celebrities are like ordinary people who look forward to this festive month. Like most us, showbiz personalities look forward to celebrating the Christmas holiday because they rarely get the chance to meet up with their relatives or spend quality time with their loved ones [63].

Moreover, I realised that celebrities are like ordinary people who commit mistakes, suffer due to peer pressure and have their own share of insecurities. I adored the acting abilities of Soha in $R D B$ and $K K C$ but this interview made me admire her as an honest human [64].

Стратегия на повышение направлена на демонстрацию жизни и деятельности представителей шоу-бизнеса исключительно с позитивных сторон. Знаменитости позиционируют себя как отличающиеся от других людей, эксперты в различных областях знаний (психология, искусство, мода, музыка, кино, спорт и т.д.), что подчинено основной цели коммуникации в сфере шоу-бизнеса - привлечению внимания зрителей/читателей. Приведём пример из нескольких названий интервью и статей по тематике шоу-бизнеса:

One-on-one with Juhi Chawla: When you are a celebrity, you can forget the life of a normal human being [65].

When you are a celebrity and the press might be your flying monkeys [66].

Celebrities are playing an ever greater role in modern culture and consumption patterns, serving as arbiters of taste, style and public opinion the world over.

For many people, film and TV stars, athletes, pop stars, the royal family, chefs and business tycoons serve as arbiters of taste, morality and public opinion, thus impacting on buying behavior [67].

Why do we treat celebrities as experts on subjects that really matter? [68].

15 Celebrities Who Want To Be Food Experts [69].

В рамках стратегии театральности представители шоу-бизнеса излагают нам в том или ином виде определённую информацию, предупреждают или побуждают нас к действию, провоцируют на что-то, прогнозируя ход развития событий и т.д. Примером может послужить следующие дискурсивные фрагменты:

Over the next four years, Lombard's image morphed more and more into that of the Cool Girl. She told Motion Picture that girls had two choices: Be modern (drive, 
play bridge, read, keep up with the latest plays, go in for sports with zest) or be a wallflower [70].

In sports other aims are pursued. You go in for sports for yourselves, you don't think, how many you will earn, you think first of all about health as you will look and what example you will show to people around, relatives and the children. First of all and I think of it, I have a daughter who grows up, there is a youth which looks at me. I want to show them that it is better to go this road, than ... [71].

Know that life isn't perfect. You will have hardships but they are meant to make you stronger. Strive for what you want and educate yourself on what you are choosing to go after. Many people many argue with emotions but a kitten can never come for a cat when the cat is packed with facts. Love yourself first then allow others to love you. - Shauna Brooks [72].

В результате анализа дискурсивных фрагментов из сферы шоу-бизнеса было выявлено, что в незначительной степени преобладает стратегия на повышение, характеризующаяся тактикой явной/ скрытой презентации, менее частотны стратегия на понижение, представленная, в частности, тактиками оскорбления и угрозы (в зависимости от уровня и качества шоу, уровня интервью), стратегия обобщения, имеющая в основе тактику сближения известных личностей и обычных людей, а также стратегия театральности с тактиками информирования, побуждения, предупреждения и др.

Еще одним системообразующим фактором дискурса являются базовые ценности, т.е. совокупность того, что представляет наибольшую значимость для адресанта (говорящего) и обусловливает, в целом, существование цели дискурса $[31 ; 33]$. Мы не подвергаем сомнению важность выявления системы базовых ценностей дискурса сферы шоубизнеса, поскольку само её существование является основой для формирования в сознании участников дискурса определённого мировоззрения, отражающего особые, присущие исключительно представителям данной социально-коммуникативной общности, варианты интерпретации действительности. Примерами контекстов вербализации основных ценностей сферы шоу-бизнеса могут послужить, в частности, приведенные ниже фрагменты. К основным ценностям дискурса сферы шоу-бизнеса относятся деньги и богатство, что видно в следующих фрагментах интервью с известными личностями:

Of course dad was very proud at what I'd achieved but also sad it wasn't in the family ownership any more. By that stage, I bought them a house; they lived very comfortably and knew they were taken care of. I took them on Concorde and flew them first-class so they got to appreciate what tennis bought me. Without tennis, I'd never have opened a club so it's all down to the game and they loved that (MONEY, WEALTH) [73]. Несмотря на то, что прямого употребления слов топеу (деньги) и wealth (богатство) в данном фрагменте нет, однако есть косвенные указания («я купил им дом, в котором они жили с комфортом», «о них заботились», «я купил им билеты на самолёт в первый класс», «открыл клуб» и т.д.).

Writers tend to suffer from back problems because they spend their time bent over a desk. I also have a Cadillac ATS. I owned a Cadillac Eldorado for 15 years, but I've just got rid of it. In addition, I have some very nice handmade acoustic guitars that cost about $\$ \mathbf{8 , 0 0 0}$ each. I also own a lot of books. I used to collect Persian rugs and real estate - you should be able to walk on and live in your money (MONEY, WEALTH) [74]. В данном интервью актёр и музыкант Эрик Айдл говорит о своём владении несколькими автомобилями представительского класса - кадиллаками разных моделей, сделанными на заказ акустическими гитарами стоимостью по 8000 долларов каждая, что он раньше коллекционировал персидские ковры и недвижимость, «жил в своих деньгах».

Ещё одной базовой ценностью англоязычного дискурса является слава, известность, например:

When you're a famous movie star and you get to go on a local news show to promote a movie that people are paying $\$ 18$ to go watch, you don't get to act like a $b^{* * * * . "}$ (FAME) [75].

Кроме того, среди базовых ценностей дискурса сферы шоу-бизнеса можно назвать статус, авторитет и власть, например:

Finally, I examine a 'spontaneous' moment of interaction between Katy Perry and her fans, this time instigated by her, which draws on the same processes as the \#ask format and shows how the celebrity has power over the audience. Perry encourages fans to sublimate their own identity and reflect her own, through directly rewarding those who do so with direct interaction (POWER, AUTHORITY) [76]. В данном фрагменте представлено описание конкретного момента взаимодействия между звездой (певицей Кэти Перри) и аудиторией, когда она буквально владела аудиторией, имела над ней власть. Однако, по нашему мнению, данная базовая ценность имеет более широкую реализацию в дискурсе, когда в принципе любой известный человек имеет определённый авторитет в обществе и некоторую власть над «простыми смертными», что может быть использовано маркетологами, например:

Celebrities are playing an ever greater role in modern culture and consumption patterns, serving as arbiters of taste, style and public opinion the world over. Their endorsement and creative input enables them to bring attention, credibility and other intangible benefits to a brand in a way that no other type of 
advertising can. This new global report analyses the ways in which marketers are exploiting celebrity power to create an emotional bond with the consumer and thus increase sales (STATUS, AUTHORITY, POWER) [67].

Базовые ценности дискурса сферы шоу-бизнеса тесно связаны с другим системообразующим признаком, а именно - реализуемыми функциями. Как известно, одной из основных функций любого вида дискурса является навязывание базовых ценностей данного дискурса адресату [14 и др.]. Под реализуемыми функциями мы понимаем назначение, роль дискурса сферы шоу-бизнеса.

Анализ эмпирического материала позволяет утверждать, что функцией любого дискурса является «воссоздание социальной реальности» $[14$, с. 26], что реализуется посредством создания коллективной идентичности. Формирование коллективной идентичности невозможно без навязывания базовых ценностей новым участникам дискурса [59]. При этом любые другие функции дискурса могут быть реализованы только при условии обращения к данной базовой функции, например:

I want to thank the fans for the last ten years.... and as the first woman to win Album of the Year at the Grammys twice, I want to say to all the young women out there...there will be people along the way who will try to undercut your success, or take credit for your accomplishments or your fame. But if you just focus on the work and you don't let those people sidetrack you, someday when you get where you're going, you'll look around and you'll know that it was you and the people who love you who put you there and that will be the greatest feeling in the world. Thank you for this moment [77]. Певица Тэйлор Свифт благодарит поклонников за признание и желает успеха молодым девушкам, которые также стремятся к тому, чтобы стать знаменитыми. Воссоздание социальной реальности происходит в нескольких моментах: в нашей жизни есть известные личности, у которых есть поклонники, за выдающиеся результаты своей деятельности звезды могут получить соответствующую награду; по жизни нам встречаются люди, которые могут помешать нашему успеху, присвоить результаты нашего труда, в противоположность им есть люди, которые нас любят; кроме того, говорится о необходимости сконцентрироваться на работе, чтобы понять, стать на свой путь в жизни и чего-то достичь. Подобным образом, в любом типе дискурса можно выделить людей с определённым социальным статусом, общественную обстановку, социальные отношения и т.д.

Какие же более частные функции реализует дискурс сферы шоу-бизнеса? Как уже говорилось выше, основными целями данного вида дискурса являются следующие: развлечение адресата, привлечение его внимания к жизни знаменитостей, формирование определённого, гламурного, «звёздного» стиля жизни и т.д. Для достижения данных целей у адресата необходимо, прежде всего, сформировать желание быть причастным к знаменитостям, элите, высшему кругу, т.е. к миру красивых, богатых, внимательно следящих за модой, пользующихся красивыми, дорогими вещами людей. После формирования потребности в обладании данными вещами, желания стать частью элиты, представители шоу-бизнеса стараются навязать новые гламурные ценности, что и является в данном случае «формированием коллективной идентичности», т.е. реализацией основной функции дискурса сферы шоу-бизнеса:

- What are the essential items every man should own?

- Calvin Klein boxers, good shoes, nice watch and...a JLS condom (Labrinth) [78].

- What are some of your favorites that you got?

I like Ed Hardy sneakers. I like Nike's Air Force One's. I like Adidas. I like Louis Vuitton - when I get classy, when I get a little casual, I wear Louis Vuitton sneakers. It's just a variety of sneakers I like, though, but them is like the main ones (Chingy) [79].

В приведённых отрывках из интервью адресант пытается переориентировать существовавшие до этого ценности зрителя/читателя на новые, гламурные, свойственные шоу-бизнесу; в центре внимания оказывается модная, «правильная» жизнь звёзд, на которую необходимо всем равняться. В данных дискурсивных фрагментах наличествует элемент брендирования (процесс создания образа для товаров определённого продавца) [80], когда различные предметы одежды и обуви, предметы домашнего обихода и т.д. выбираются звёздами даже не из принципа качества или удобства, а из принципа известности бренда: спортивная одежда и обувь - значит по крайней мере Nike или Adidas, одежды и мужского нижнего белья - Calvin Klein, чемоданов, сумок - Louis Vuitton или Michael Kors, духов - Chanel, часов - Cartier и т.д. И обычные люди, следуя последней моде, слепо подражая своим кумирам, также «окунаются» в мир гламура.

Таким образом, среди дополнительных (вспомогательных) функций дискурса сферы шоу-бизнеса следует отметить следующие: утверждение двойного жизненного стандарта (жизнь простых людей и жизнь знаменитостей), создание мифа о женщине/мужчине - образце для подражания («идеальном мужчине», «идеальной женщине») и т.д.

Ещё одним системообразующим фактором являются дискурсивные формулы- «своеобразные обороты речи, свойственные общению в соответствующем социальном институте» [31, с. 280], которые объединяют всех представителей данного 


\section{Интертекстуальность}

социума. В рамках дискурса сферы шоу-бизнеса можно выделить определённые дискурсивные формулы, или языковые средства, используемые участниками коммуникации для выражения той или иной позиции говорящего и маркирования его принадлежности к определённому дискурсу. Так, например, к данным языковым средствам можно отнести терминологию шоу-бизнеса, экспрессивную и эмоционально-оценочную, неформальную лексику, профессионализмы, сленг и т.д. Приведём ниже дискурсивные фрагменты, в которых присутствуют неформальная лексика и элементы профессионального сленга:

- We have seen photos of you online at dance class. While you are still in school, what other courses are you studying?

- I want to keep my fans (informal) guessing, so I can't really say (laughs). But, what I can say is that I'll give you a tip. Here's the tip - I love showbiz (professional slang) [81].

- Why showbiz? (professional slang)

- Because I'm a show off! Haha! But also because I love it with every molecule of my being! [82].

Кроме того, в статье по шоу-бизнесу практически в обязательном порядке в том или ином объёме присутствует терминология, например:

Perrotta is one of only four people in the rehearsals, including the star, the professional dancing partner and the field producer.

One of our pro dancers (informal) was generous and arranged for a food truck to come by the rehearsal hall for lunch one day. The cast and crew got to have as much as we wanted... [83].

Еще одним параметром выделения дискурса сферы шоу-бизнеса являются прецедентные, или культурогенные, тексты [см.: 31; 33], т.е. дискурсивные отрывки, свойственные исключительно сфере шоу-бизнеса, несущие информацию о шоу-бизнес культуре, знаменитостях, моде, музыке, кино и т.д. К подобным текстам мы относим такие, которые несут информацию о шоу-бизнесе как сфере человеческой деятельности, которые знают многие люди, имеющие прямое или косвенное отношение к шоу-бизнесу, на которые многие из них ссылаются, поскольку они считаются важными для данной сферы. Например, «классической» для сферы шоу-бизнеса считается песня Ирвинга Берлина (Irving Berlin) «Нет такого бизнеса, как шоу-бизнес» («There's No Business Like Show Business»), написанная в 1946 г. для мюзикла «Энни получает Ваше оружие» (Annie Get Your Gun). Приведём фрагмент песни:

There's no business like show business

Like no business I know

Everything about it is appealing
Everything that traffic will allow

Nowhere could you get that happy feeling

When you are stealing that extra bow

There's no people like show people

They smile when they are low

Even with a turkey that you know will fold

You may be stranded out in the cold

Still you wouldn't change it for a sack of gold

Let's go on with the show...

В данной песне в шутливой форме повествуется о том, что шоу-бизнес - это особая сфера человеческой деятельности, что шоумены - это особые люди, что жить в гламуре - это здорово, и т.д. Прецедентный характер названия данной песни, в частности, подтверждается тем фактом, что в 1954 г. режиссёром Уолтером Лангом был снят одноименный фильм (мюзикл-комедия-драма) «There's No Business Like Show Business». Кроме того, в 2003 г. у Бернда Шмитта, Дэвида Роджерса и Карен Вротсос вышла книга «Нет такого бизнеса, который бы не был шоу-бизнесом» (полное оригинальное название: «There's No Business That's Not Show Business. Marketing in an Experience Culture»), в которой эпиграфом служит фрагмент из указанной выше песни Ирвинга Берлина. Кроме того, в 2006 г. под авторством Алана Янга (Alan Young) была опубликована книга «Нет такого бизнеса, каким шоу-бизнес... был» («There’s No Business Like Show Business...Was»). Таким образом, мы отмечаем наличие англоязычных прецедентных текстов сферы шоу-бизнеса.

Проанализировав разнообразные тексты интервью, выступлений знаменитостей, блоги и записи интернет-форумов, тексты глянцевых журналов и т.д., мы приходим к выводу о том, что представленный в начале статьи набор системообразующих признаков полностью задействован в дискурсе сферы шоу-бизнеса. Отмеченные характеристики позволяют не только отнести адресанта (говорящего) к данному виду дискурса, но и в определённой мере прогнозировать речевое поведение субъекта речи и как представителя определённого вида дискурса, и как самостоятельной языковой личности.

Подчеркнём также, что характеристики дискурса сферы шоу-бизнеса соотносятся с особенностями современной культуры: персонализация, сетевой характер, клиповость, символический и виртуальный характер, изменчивость с течением времени, гедонистичность, множественность, разрушение границ между различными областями знания и т.д.

Таким образом, мы приходим к выводу о правомерности выделения дискурса шоу-бизнеса как специфической сферы англоязычного дискурсив- 
ного пространства. Данный вид дискурса обладает всеми системообразующими признаками: имеет своих участников, цели, стратегии и тактики коммуникации, хронотоп, тематику коммуникации, ба- зовые ценности, разновидности и жанры дискурса, прецедентные тексты, дискурсивные формулы, а также функции, реализуемые в рамках дискурсивного процесса.

\section{Список литературы:}

1. Алимурадов О.А., Блинова Д.Е., Раздуев А.В. Фреймовое моделирование языковой картины мира, репрезентируемой в англоязычном детском дискурсе // Вестник Иркутского государственного лингвистического университета. 2010. № 4. С. 6-13.

2. Алимурадов О.А., Григорьева Н.В. Интеракциональная природа дискурса и некоторые критерии его осмысленности // Филологические науки. Вопросы теории и практики. 2009. № 2. С. 31-37.

3. Алимурадов О.А., Гусева М.А. Структурная и признаковая модели концепта BEAUTY (КРАСОТА), объективируемого в современном англоязычном женском дискурсе // Вопросы когнитивной лингвистики. 2010. № 3. С. 12-19.

4. Алимурадов O.А., Микаелян М.Е. Интегрирующий содержательный компонент концепта CRIME и закономерности актуализации его признаков в англоязычном художественном дискурсе // Вестник Пятигорского государственного лингвистического университета. 2009. № 4. С. 44-50.

5. Алимурадов О.А., Милетова Е.В. Метафорические модели, вербализующиеся с участием имён прилагательных и реализуемые в современном англоязычном искусствоведческом дискурсе // Вопросы когнитивной лингвистики. 2013. № 4(37). С. 51-60.

6. Алимурадов О.А., Хасуева М. Сущность явления суггестии в медиа-дискурсе и основные факторы успешности данного процесса // Язык. Текст. Дискурс. 2010. № 8. С. 363-375.

7. Алимурадов О.А., Шлепкина М.А. Инновационные лексические процессы в системе стереотипных конструкций современного англоязычного делового дискурса: аббревиация и сокращение // Филологические науки. Вопросы теории и практики. 2010. № 1-1. С. 20-29.

8. Лату М.Н. Военная терминология в современном политическом дискурсе // Политическая лингвистика. 2011. № 3. С. 98-104.

9. Лату М.Н. Псевдонаучный дискурс и псевдотермины: постановка проблемы изучения // Вестник Пятигорского государственного лингвистического университета. 2012. № 3. С. 76-79.

10. Раздуев А.В. Дискурс сферы нанотехнологий как вид научного дискурса (на материале современного английского языка) // Вестник Челябинского государственного университета. 2013. № 37(328). С. 52-55.

11. Раздуев А.В., Хакиева 3.У. Основные индивидуальные (вариативные) характеристики англоязычных систем строительной и нанотехнологической терминологии // Теоретические и прикладные аспекты изучения речевой деятельности. 2012. № 7. С. 191-206.

12. Чернышенко А.Г., Алимурадов О.А. Прикладная терминосистема с функциональной точки зрения: терминологический компонент англоязычного дискурса медиации // Вестник Брянского государственного университета. 2014. № 2. C. 408-415.

13. Harris Z. Discourse Analysis: A sample text // Language. 1952. Vol. 28. № 4. P. 474-494.

14. Филлипс Л., Йоргенсен, М. Дискурс-анализ. Теория и метод / Пер. с англ. Харьков: Изд-во Гуманитарный Центр, 2004. $336 \mathrm{c.}$

15. Laclau E., Mouffe C. Hegemony and Socialist Strategy. Towards a Radical Democratic Politics. London: Verso, 1985.240 p.

16. Foucault M.L. Archeologie du savoir. Paris: Gallimard, 1973. 153 p.

17. Чернявская B.Е. Дискурс власти и власть дискурса: проблемы речевого воздействия: учеб. пособие. М.: Флинта: Наука, 2006. 136 с.

18. Кибрик А.А., Плунгян В.А. Функционализм // Фундаментальные направления современной американской лингвистики. Сборник обзоров / Ред.: А.А. Кибрик, И.М. Кобозева, И.А. Секерина. М.: Изд-во МГУ, 1997. C. 276-339.

19. Mann W.C., Thompson S.A. Rhetorical Structure Theory // Toward a Functional Theory of Text Organization. 1988. P. $243-281$.

20. Givon T. Discourse and Syntax. N.Y.: Academic Press, 1979. 320 p.

21. Leech G. Principles of pragmatics. London: Longman, 1983. 257 p.

22. Звегинцев В.А. О цельнооформлености единиц текста // Известия АН СССР, серия ЛЯ. Т. 39, 1980. № 1. С. $13-21$.

23. Борботько В.Г. Принципы формирования дискурса: от психолингвистики к лингвосинергетике. М.: КомКнига, 2006. 288 c.

24. Дейк Т.А. ван. Язык. Познание. Коммуникация / Сост. В.В. Петрова. Под ред. В.И. Герасимова. М.: Прогресс, 1989.312 с.

25. Courtes J. La grande traque des valeurs textuelles: Quelques principes liminaires pour comprendre la GT // Le français dans le monde. 1985. № 192. P. 28-34.

26. Charaudeau P. Langage et discours. Paris: Hachette, 1983. 176 p.

27. Арутюнова Н.Д. Метафора и дискурс / Пер. с англ., фр., нем., исп., польск. яз. Вступ. ст. и сост. Н.Д. Арутюновой // Теория метафоры. Сборник научных трудов. М.: Прогресс, 1990. 512 с.

28. Караулов Ю.Н., Петров В.В. От грамматики текста к когнитивной теории дискурса // Дейк Т.А. ван. Язык. Познание. Коммуникация / Пер. с англ. М.: Прогресс, 1989. 312 с.

29. Шинкаренкова М.Б. Метафорическое моделирование художественного мира в дискурсе русской рок-поэзии: Дис. ... канд. филол. наук. Екатеринбург, 2005. 204 с.

30. Гаврилова М.В. Критический дискурс-анализ в современной зарубежной лингвистике. СПб.: Изд-во С.-Петербургского университета, 2003. 42 с.

31. Карасик В.И. Языковой круг: личность, концепты, дискурс. М.: Гнозис, 2004. 390 с. 


\section{Интертекстуальность}

32. Чудинов А.П. Россия в метафорическом зеркале: когнитивное исследование политической метафоры (1991-2000). Екатеринбург: Урал. гос. пед. ун-т, 2001. 238 с.

33. Карасик В.И. О типах дискурса // Языковая личность: институциональный и персональный дискурс: сб. науч. тр. Волгоград: Перемена, 2000. С. 5-20.

34. Кубрякова Е.С., Александрова О.В. О контурах новой парадигмы знания в лингвистике // Структура и семантика художественного текста: доклады VII междунар. конф. М., 1999. С. 186-197.

35. Шейгал Е.И. Семиотика политического дискурса. М.: Гнозис, 2004. 324 с.

36. Гаврилов А.А. Средства воздействия СМИ на общественное сознание в условиях информационного общества // Молодой ученый. 2012. № 8. С. 152-155.

37. Калиберда Е.Г. Связи с общественностью: вводный курс. Учебное пособие. М.: Логос, 2003. 144 с.

38. Моисеев В.А. Паблик рилейшнз: теория и практика. М.: 000 «ИКФ Омега-Л», 2001. 376 с.

39. Синяева И.М. Паблик рилейшнз в коммерческой деятельности: учебник / Под ред. проф. Г.А. Васильева. М.: Юнити, 2000. 287 c.

40. Федотова Л. Паблик рилейшнз и общественное мнение. СПб.: Питер, 2001. 352 с.

41. Чумиков А.Н. Связи с общественностью: теория и практика. М.: Дело, 2003. 495 с.

42. Гопко В.В. «Шоуизация» общества // Человек в контексте эпохи: Материалы регион. науч. конференции, посвященной 85-летию М.Е. Бударина 30 ноября 2005 г., г. Омск / Омск. гос. пед. ун-т; ред. И.И. Кротт [и др.]. Омск: ОмГПУ, 2005. С. 46-52.

43. Русакова О.Ф., Русаков B.M. PR-Дискурс: Теоретико-методологический анализ. Екатеринбург: УрО РАН, Институт международных связей, 2008. 340 с.

44. Английский сленг. URL: http://www.englishinrussia.ru/ru/blog/language/английский-сленг-сооl (дата обращения: 01.01.2016).

45. Caldwell J.T. Televisuality: Style, Crisis, and Authority in American Television. New Brunswick, NJ: Rutgers University Press, 1995. $456 \mathrm{p}$.

46. Halper D.L. Icons of Talk: The Media Mouths That Changed America. Westport, CT: Greenwood Press, 2008. 392 p.

47. Kubey R. Creating Television: Conversations with the People behind 50 Years of American TV Lawrence. Mahwah, NJ Erlbaum Associates, 2004. 522 p.

48. Suman M.A. Religion and Prime Time Television. Westport, CT: Praeger Publishers, 1997. 196 p.

49. Ponce De Leon, Ch.L. Self-Exposure: Human-Interest Journalism and the Emergence of Celebrity in America, 1890-1940. Chapel Hill, NC: University of North Carolina Press, 2002. 347 p.

50. Колтышева С.Я. Метафорическое моделирование образа шоу-бизнеса в российском и американском массмедийном дискурсе: Дис. ... канд. филол. наук. Екатеринбург, 2009. 240 с.

51. Madonna. URL: http://www.interviewmagazine.com/music/Madonna (дата обращения: 01.01.2016).

52. How Terence Nance complicates things. URL: http://www.interviewmagazine.com/film/terence-nance-anoversimplification-of-her-beauty/ (дата обращения: 01.01.2016).

53. Interview of Iain Calder. URL: http://www.yale.edu/yje/calder.html (дата обращения: 01.11.2015).

54. Шоу-бизнес. Wikipedia. URL: http://ru.wikipedia.org/wiki/Шоу-бизнес (дата обращения: 01.01.2016).

55. Общая психология. Словарь / Под ред. А.В. Петровского // Психологический лексикон. Энциклопедический словарь в шести томах / Ред.-сост. Л.А. Карпенко. Под общ. ред. А.В. Петровского. М.: ПЕР СЭ, 2005. 784 с.

56. Х Хронотоп. Wikipedia. URL: http://ru.wikipedia.org/wiki/Хронотоп (дата обращения: 01.01.2016).

57. Борисова И.Н. Дискурсивные стратегии в разговорном диалоге // Русская разговорная речь как явление городской культуры / Под ред. Т.В. Матвеевой. Екатеринбург: АРГО, 1996. С. 21-48.

58. Сковородников А.П. О необходимости разграничения понятий «риторический прием», «стилистическая фигура», «речевая тактика», «речевой жанр» в практике терминологической лексикографии // Риторика ↔ Лингвистика. Вып. 5: сб. статей. Смоленск: СГПУ, 2004. С. 5-11.

59. Михалева О.Л. Дискурс объекта vs дискурс субъекта: системообразующие признаки. URL: http://rus-lang.isu.ru/ about/group/mikhaleva/state15/ (дата обращения: 01.01.2015).

60. Ten Hollywood Celebrities Who Have Spoken Out About Their Religion. URL: http://www.hollywoodreporter.com/news/ religious-hollywood-celebrities-who-have-818162 (дата обращения: 01.01.2016).

61. I'm a Celebrity. Willie: Antony and Dougie are f***ing thieves. URL: http://www.digitalspy.com/tv/im-a-celebrity/news/ a353767/im-a-celebrity-willie-antony-and-dougie-are-fing-thieves/ (дата обращения: 01.01.2016).

62. Diet Secrets of the Stars. URL: http://exercisedietfit.blogspot.com/2016/02/7-diet-secrets-of-stars_1.html (дата обращения: 01.01.2016).

63. Stars become lesser mortals. URL: https://andronico.wordpress.com/2010/12/27/stars-become-lesser-mortals/ (дата обращения: 01.01.2016).

64. Genuine interview. URL: http://www.thesundayindian.com/en/story/genuine-interview-/44/4241/ (дата обращения: 01.01.2016).

65. One-on-one with Juhi Chawla: When you are a celebrity, you can forget the life of a normal human being. URL: http://news. yahoo.com/photos/one-one-juhi-chawla-celebrity-043040244/no-genuinely-loved-script-am-photo-043040470.html (дата обращения: 01.01.2016).

66. When you are a celebrity and the press might be your flying monkeys. URL: https://www.reddit.com/r/narcsinthewild/ comments/3rhvoa/when_you_are_a_celebrity_and_the_press_might_be/ (дата обращения: 01.01.2016).

67. Celebrity Power and Its Influence on Global Consumer Behaviour. URL: http://www.euromonitor.com/celebrity-powerand-its-influence-on-global-consumer-behaviour/report (дата обращения: 01.01.2016).

68. Why do we treat celebrities as experts on subjects that really matter. URL: http://www.telegraph.co.uk/men/thinkingman/11185619/Why-do-we-treat-celebrities-as-experts-on-subjects-that-really-matter.html (дата обращения: 01.01.2016). 


\section{Филология: научные исследования 1(21) • 2016}

69. Celebrities WhoWant To Be Food Experts.URL:http://www.huffingtonpost.com/2014/01/10/celebrities-food_n_4563189. html (дата обращения: 01.01.2016).

70. Jennifer Lawrence And The History Of Cool Girls. URL: http://www.buzzfeed.com/annehelenpetersen/jennifer-lawrenceand-the-history-of-cool-girls\#.bvqlrRnQY (дата обращения: 01.01.2016).

71. Alexandr Emelyanenko about Return to Sports, Lives in the Monastery, Policy, Tattoos and the Crime. URL: http://wrestling. com.ua/en/news/article/pankration/13_05_23_aleksandr_emelyanenko_o_vozvraschenii_v_sport_jizni_v_monastyire_ politike_tatuirovkah_i_kriminale/ (дата обращения: 01.01.2016).

72. Celebrity XO Exclusive Interview with Shauna Brooks. URL: http://www.celebrityxo.com/celebrities-xo/celebrityxoexclusive-interview-with-shauna-brooks/ (дата обращения: 01.01.2016).

73. David Lloyd: 'I turned $£ 10 \mathrm{k}$ into $£ 1 \mathrm{~m}$ in 10 years - then built a home for Sir Cliff'. URL: http://www.telegraph.co.uk/finance/ personalfinance/fameandfortune/12099138/David-Lloyd-I-turned-10k-into-1m-in-10-years-then-built-a-home-for-SirCliff.html (дата обращения: 01.01.2016).

74. Eric Idle: The BBC paid us £2,000 a series for Monty Python. URL: http://www.telegraph.co.uk/finance/personalfinance/ fameandfortune/12086923/Eric-Idle-The-BBC-paid-us-2000-a-series-for-Monty-Python.html (дата обращения: 01.01.2016).

75. You don't know if she's on her period: The View hosts clash over Cara Delevingne's awkward interview. URL: http://www. mirror.co.uk/3am/celebrity-news/you-dont-know-shes-period-6161526 (дата обращения: 01.01.2016).

76. Twitter and the celebrity interview. URL: http://www.tandfonline.com/doi/full/10.1080/19392397.2015.1062641 (дата обращения: 01.01.2016).

77. Taylor Swift Just Clapped Back at Kanye West So Hard During Her Album of the Year Speech. URL: http://www.seventeen.com/ celebrity/music/news/a38118/taylor-swift-just-clapped-back-at-kanye-west-so-hard/ (дата обращения: 01.01.2016).

78. GQ Magazine. URL: http://www.gq-magazine.co.uk/style/articles/2013-02/22/labrinth-interview-music-and-stylelondon-fashion-weekend (дата обращения: 30.12.2015).

79. Exclusive Interview with Chingy. URL: http://www.tv.com/news/exclusive-interview-with-chingy-6244/ (дата обращения: 01.01.2016).

80. Брендирование. URL: www.brandbook.ru/web/brjendirovanije/ (дата обращения: 01.01.2016).

81. BN Saturday Celebrity Interview: “Clarence Peters \& Don Jazzy Are Really Hot / Controversial Singer Maheeda Dishes on Her 'Sexy Propaganda', Married Life, Raising Her Teenage Daughter \& Much More. URL: http://www.bellanaija.com/2013/10/ bn-saturday-celebrity-interview-clarence-peters-don-jazzy-are-really-hot-controversial-singer-maheeda-dishes-on-hersexy-propaganda-married-life-raising-her-teenage-daughter-much-more/ (дата обращения: 01.01.2016).

82. I love showbiz with every molecule of my being! Dilshad Burman. URL: http://www.sagennext.com/2013/04/26/i-loveshowbiz-with-every-molecule-of-my-being-dilshad-burman/ (дата обращения: 01.01.2016).

83. Dancing with the Stars. Allen Image. URL: http://www.collin.edu/pr_images/magazinePDFs/201301Dancing WithTheStarsAllenImage.pdf (дата обращения: 01.01.2016).

84. Занковский А.Н., Нарциссова С.Ю. Дискурс в виртуальном общении: мотивационно-потребностные и ролевые детерминанты // Психология и психотехника. 2015. № 6. С. 560-569. DOI: 10.7256/2070-8955.2015.6.15501.

\section{References (transliterated):}

1. Alimuradov O.A., Blinova D.E., Razduev A.V.Freimovoemodelirovanieyazykovoi kartiny mira, reprezentiruemoiv angloyazychnom detskom diskurse // Vestnik Irkutskogo gosudarstvennogo lingvisticheskogo universiteta. 2010. № 4. S. 6-13.

2. Alimuradov O.A., Grigor'eva N.V. Interaktsional'naya priroda diskursa i nekotorye kriterii ego osmyslennosti // Filologicheskie nauki. Voprosy teorii i praktiki. 2009. № 2. S. 31-37.

3. Alimuradov O.A., Guseva M.A. Strukturnaya i priznakovaya modeli kontsepta BEAUTY (KRASOTA), ob"ektiviruemogo v sovremennom angloyazychnom zhenskom diskurse // Voprosy kognitivnoi lingvistiki. 2010. № 3. S. 12-19.

4. Alimuradov O.A., Mikaelyan M.E. Integriruyushchii soderzhatel'nyi komponent kontsepta CRIME i zakonomernosti aktualizatsii ego priznakov v angloyazychnom khudozhestvennom diskurse // Vestnik Pyatigorskogo gosudarstvennogo lingvisticheskogo universiteta. 2009. № 4. S. 44-50.

5. Alimuradov O.A., Miletova E.V. Metaforicheskie modeli, verbalizuyushchiesya s uchastiem imen prilagatel'nykh i realizuemye v sovremennom angloyazychnom iskusstvovedcheskom diskurse // Voprosy kognitivnoi lingvistiki. 2013. № 4(37). S. 51-60.

6. Alimuradov O.A., Khasueva M. Sushchnost' yavleniya suggestii v media-diskurse i osnovnye faktory uspeshnosti dannogo protsessa // Yazyk. Tekst. Diskurs. 2010. № 8. S. 363-375.

7. Alimuradov O.A., Shlepkina M.A. Innovatsionnye leksicheskie protsessy v sisteme stereotipnykh konstruktsii sovremennogo angloyazychnogo delovogo diskursa: abbreviatsiya i sokrashchenie // Filologicheskie nauki. Voprosy teorii i praktiki. 2010. № 1-1. S. 20-29.

8. Latu M.N. Voennaya terminologiya v sovremennom politicheskom diskurse // Politicheskaya lingvistika. 2011. № 3. S. 98-104.

9. Latu M.N. Psevdonauchnyi diskurs i psevdoterminy: postanovka problemy izucheniya // Vestnik Pyatigorskogo gosudarstvennogo lingvisticheskogo universiteta. 2012. № 3. S. 76-79.

10. Razduev A.V. Diskurs sfery nanotekhnologii kak vid nau chnogo diskursa (na materiale sovremennogo angliiskogo yazyka) // Vestnik Chelyabinskogo gosudarstvennogo universiteta. 2013. № 37(328). S. 52-55.

11. Razduev A.V., Khakieva Z.U. Osnovnye individual'nye (variativnye) kharakteristiki angloyazychnykh sistem stroitel'noi i nanotekhnologicheskoi terminologii // Teoreticheskie i prikladnye aspekty izucheniya rechevoi deyatel’nosti. 2012. № 7. S. 191-206.

12. Chernyshenko A.G., Alimuradov O.A. Prikladnaya terminosistema s funktsional'noi tochki zreniya: terminologicheskii komponent angloyazychnogo diskursa mediatsii // Vestnik Bryanskogo gosudarstvennogo universiteta. 2014. № 2. S. 408-415.

13. Harris Z. Discourse Analysis: A sample text // Language. 1952. Vol. 28. № 4. P. 474-494.

14. Fillips L., Iorgensen M. Diskurs-analiz. Teoriya i metod / Per. s angl. Khar'kov: Izd-vo Gumanitarnyi Tsentr, 2004.336 s.

15. Laclau E., Mouffe C. Hegemony and Socialist Strategy. Towards a Radical Democratic Politics. London: Verso, 1985.240 p.

16. Foucault M.L. Archeologie du savoir. Paris: Gallimard, 1973. 153 p. 


\section{Интертекстуальность}

17. Chernyavskaya V.E. Diskurs vlasti i vlast' diskursa: problemy rechevogo vozdeistviya: ucheb. posobie. M.: Flinta: Nauka, 2006. $136 \mathrm{~s}$.

18. Kibrik A.A., Plungyan V.A. Funktsionalizm // Fundamental'nye napravleniya sovremennoi amerikanskoi lingvistiki. Sbornik obzorov / Red.: A.A. Kibrik, I.M. Kobozeva, I.A. Sekerina. M.: Izd-vo MGU, 1997. S. 276-339.

19. Mann W.C., Thompson S.A. Rhetorical Structure Theory // Toward a Functional Theory of Text Organization. 1988. P. $243-281$.

20. Givon T. Discourse and Syntax. N.Y.: Academic Press, 1979. 320 p.

21. Leech G. Principles of pragmatics. London: Longman, 1983. 257 p.

22. Zvegintsev V.A. 0 tsel'nooformlenosti edinits teksta // Izvestiya AN SSSR, seriya LYa. T. 39, 1980. № 1. S. 13-21.

23. Borbot'ko V.G. Printsipy formirovaniya diskursa: ot psikholingvistiki k lingvosinergetike. M.: KomKniga, 2006.288 s.

24. Deik T.A. van. Yazyk. Poznanie. Kommunikatsiya / Sost. V.V. Petrova. Pod. red. V.I. Gerasimova. M.: Progress, 1989.312 s.

25. Courtes J. La grande traque des valeurs textuelles: Quelques principes liminaires pour comprendre la GT // Le français dans le monde. 1985. № 192. P. 28-34.

26. Charaudeau P. Langage et discours. Paris: Hachette, 1983. $176 \mathrm{s.}$

27. Arutyunova N.D. Metafora i diskurs / Per. s angl., fr., nem., isp., pol'sk. yaz. Vstup. st. i sost. N.D. Arutyunovoi // Teoriya metafory. Sbornik nauchnykh trudov. M.: Progress, 1990. 512 s.

28. Karaulov Yu.N., Petrov V.V. Ot grammatiki teksta k kognitivnoi teorii diskursa // Deik T.A. van. Yazyk. Poznanie. Kommunikatsiya / Per. s angl. M.: Progress, 1989. 312 s.

29. Shinkarenkova M.B. Metaforicheskoe modelirovanie khudozhestvennogo mira v diskurse russkoi rok-poezii: Dis. ... kand. filol. nauk. Ekaterinburg, 2005. 204 s.

30. Gavrilova M.V. Kriticheskii diskurs-analiz v sovremennoi zarubezhnoi lingvistike. SPb.: Izd-vo S.-Peterburgskogo universiteta, 2003. $42 \mathrm{~s}$.

31. Karasik V.I. Yazykovoi krug: lichnost', kontsepty, diskurs. M.: Gnozis, 2004. 390 s.

32. Chudinov A.P. Rossiya v metaforicheskom zerkale: kognitivnoe issledovanie politicheskoi metafory (1991-2000). Ekaterinburg: Ural. gos. ped. un-t., 2001.238 s.

33. Karasik V.I. O tipakh diskursa // Yazykovaya lichnost': institutsional'nyi i personal'nyi diskurs: sb. nauch. tr. Volgograd: Peremena, 2000. S. 5-20.

34. Kubryakova E.S., Aleksandrova O.V. O konturakh novoi paradigmy znaniya v lingvistike // Struktura i semantika khudozhestvennogo teksta: doklady VII mezhdunar. konf. M., 1999. S. 186-197.

35. Sheigal E.I. Semiotika politicheskogo diskursa. M.: Gnozis, 2004. 324 s.

36. Gavrilov A.A. Sredstva vozdeistviya SMI na obshchestvennoe soznanie v usloviyakh informatsionnogo obshchestva // Molodoi uchenyi. 2012. № 8. S. 152-155.

37. Kaliberda E.G. Svyazi s obshchestvennost'yu: vvodnyi kurs. Uchebnoe posobie. M.: Logos, 2003. $144 \mathrm{s.}$

38. Moiseev V.A. Pablik rileishnz: teoriya i praktika. M.: O00 «IKF Omega-L», 2001. 376 s.

39. Sinyaeva I.M. Pablik rileishnz v kommercheskoi deyatel'nosti: Uchebnik / Pod red. prof. G.A. Vasil'eva. M.: Yuniti, 2000.287 s.

40. Fedotova L. Pablik rileishnz i obshchestvennoe mnenie. SPb.: Piter, 2001. 352 s.

41. Chumikov A.N. Svyazi s obshchestvennost'yu: teoriya i praktika. M.: Delo, 2003. 495 s.

42. Gopko V.V. «Shouizatsiya» obshchestva // Chelovek v kontekste epokhi: Materialy region. nauch. konferentsii, posvyashchennoi 85-letiyu M.E. Budarina 30 noyabrya 2005 g., g. Omsk / Omsk. gos. ped. un-t; red. I.I. Krott [i dr.]. Omsk: OmGPU, 2005. S. 46-52.

43. Rusakova O.F., Rusakov V.M. PR-Diskurs: Teoretiko-metodologicheskii analiz. Ekaterinburg: UrO RAN, Institut mezhdunarodnykh svyazei, 2008. 340 s.

44. Angliiskii sleng. URL: http://www.englishinrussia.ru/ru/blog/language/angliiskii-sleng-cool (data obrashcheniya: 01.01.2016).

45. Caldwell J.T. Televisuality: Style, Crisis, and Authority in American Television. New Brunswick, NJ: Rutgers University Press, 1995. $456 \mathrm{p}$.

46. Halper D.L. Icons of Talk: The Media Mouths That Changed America. Westport, CT: Greenwood Press, 2008.392 p.

47. Kubey R. Creating Television: Conversations with the People behind 50 Years of American TV Lawrence. Mahwah, NJ Erlbaum Associates, 2004. 522 p.

48. Suman M.A. Religion and Prime Time Television. Westport, CT: Praeger Publishers, 1997. 196 p.

49. Ponce De Leon, Ch.L. Self-Exposure: Human-Interest Journalism and the Emergence of Celebrity in America, 1890-1940. Chapel Hill, NC: University of North Carolina Press, 2002.347 p.

50. Koltysheva S.Ya. Metaforicheskoe modelirovanie obraza shou-biznesa v rossiiskom i amerikanskom massmediinom diskurse: Dis. ... kand. filol. nauk. Ekaterinburg, 2009. $240 \mathrm{~s}$.

51. Madonna. URL: http://www.interviewmagazine.com/music/Madonna (data obrashcheniya: 01.01.2016).

52. How Terence Nance complicates things. URL: http://www.interviewmagazine.com/film/terence-nance-anoversimplification-of-her-beauty/ (data obrashcheniya: 01.01.2016).

53. Interview of Iain Calder. URL: http://www.yale.edu/yje/calder.html (data obrashcheniya: 01.11.2015).

54. Shou-biznes. Wikipedia. URL: http://ru.wikipedia.org/wiki/Shou-biznes (data obrashcheniya: 01.01.2016).

55. Obshchaya psikhologiya. Slovar' / Pod red. A.V. Petrovskogo // Psikhologicheskii leksikon. Entsiklopedicheskii slovar' v shesti tomakh / Red.-sost. L.A. Karpenko. Pod obshch. red. A.V. Petrovskogo. M.: PER SE, 2005. 784 s.

56. Khronotop. Wikipedia. URL: http://ru.wikipedia.org/wiki/Khronotop (data obrashcheniya: 01.01.2016).

57. Borisova I.N. Diskursivnye strategii v razgovornom dialoge // Russkaya razgovornaya rech' kak yavlenie gorodskoi kul'tury / Pod red. T.V. Matveevoi. Ekaterinburg: ARGO, 1996. S. 21-48.

58. Skovorodnikov A.P. O neobkhodimosti razgranicheniya ponyatii «ritoricheskii priem», «stilisticheskaya figura», «rechevaya taktika», «rechevoi zhanr» v praktike terminologicheskoi leksikografii // Ritorika $\leftrightarrow$ Lingvistika. Vyp. 5: sb. statei. Smolensk: SGPU, 2004. S. 5-11.

59. Mikhaleva O.L. Diskurs ob"ekta vs diskurs sub"ekta: sistemoobrazuyushchie priznaki. URL: http://rus-lang.isu.ru/about/ group/mikhaleva/state15/ (data obrashcheniya: 01.01.2015). 
60. Ten Hollywood Celebrities Who Have Spoken Out About Their Religion. URL: http://www.hollywoodreporter.com/news/ religious-hollywood-celebrities-who-have-818162 (data obrashcheniya: 01.01.2016).

61. I'm a Celebrity. Willie: Antony and Dougie are $\mathrm{f}^{* * *}$ ing thieves. URL: http://www.digitalspy.com/tv/im-a-celebrity/news/ a353767/im-a-celebrity-willie-antony-and-dougie-are-fing-thieves/ (data obrashcheniya: 01.01.2016).

62. Diet Secrets of the Stars. URL: http://exercisedietfit.blogspot.com/2016/02/7-diet-secrets-of-stars_1.html (data obrashcheniya: 01.01.2016).

63. Stars become lesser mortals. URL: https://andronico.wordpress.com/2010/12/27/stars-become-lesser-mortals/ (data obrashcheniya: 01.01.2016).

64. Genuine interview. URL: http://www.thesundayindian.com/en/story/genuine-interview-/44/4241/ (data obrashcheniya: 01.01.2016).

65. One-on-one with Juhi Chawla: When you are a celebrity, you can forget the life of a normal human being. URL: http://news. yahoo.com/photos/one-one-juhi-chawla-celebrity-043040244/no-genuinely-loved-script-am-photo-043040470.html (data obrashcheniya: 01.01.2016).

66. When you are a celebrity and the press might be your flying monkeys. URL: https://www.reddit.com/r/narcsinthewild/ comments/3rhvoa/when_you_are_a_celebrity_and_the_press_might_be/ (data obrashcheniya: 01.01.2016).

67. Celebrity Power and Its Influence on Global Consumer Behaviour. URL: http://www.euromonitor.com/celebrity-powerand-its-influence-on-global-consumer-behaviour/report (data obrashcheniya: 01.01.2016).

68. Why do we treat celebrities as experts on subjects that really matter. URL: http://www.telegraph.co.uk/men/thinkingman/11185619/Why-do-we-treat-celebrities-as-experts-on-subjects-that-really-matter.html (data obrashcheniya: 01.01.2016).

69. CelebritiesWhoWant To BeFood Experts.URL:http://www.huffingtonpost.com/2014/01/10/celebrities-food_n_4563189. html (data obrashcheniya: 01.01.2016).

70. Jennifer Lawrence And The History Of Cool Girls. URL: http://www.buzzfeed.com/annehelenpetersen/jennifer-lawrenceand-the-history-of-cool-girls\#.bvqlrRnQY (data obrashcheniya: 01.01.2016).

71. Alexandr Emelyanenko about Return to Sports, Lives in the Monastery, Policy, Tattoos and the Crime. URL: http://wrestling. com.ua/en/news/article/pankration/13_05_23_aleksandr_emelyanenko_o_vozvraschenii_v_sport_jizni_v_monastyire_ politike_tatuirovkah_i_kriminale/ (data obrashcheniya: 01.01.2016).

72. Celebrity XO Exclusive Interview with Shauna Brooks. URL: http://www.celebrityxo.com/celebrities-xo/celebrityxoexclusive-interview-with-shauna-brooks/ (data obrashcheniya: 01.01.2016).

73. David Lloyd: 'I turned $£ 10 \mathrm{k}$ into $£ 1 \mathrm{~m}$ in 10 years - then built a home for Sir Cliff'. URL: http://www.telegraph.co.uk/finance/ personalfinance/fameandfortune/12099138/David-Lloyd-I-turned-10k-into-1m-in-10-years-then-built-a-home-for-SirCliff.html (data obrashcheniya: 01.01.2016).

74. Eric Idle: The BBC paid us $£ 2,000$ a series for Monty Python. URL: http://www.telegraph.co.uk/finance/personalfinance/ fameandfortune/12086923/Eric-Idle-The-BBC-paid-us-2000-a-series-for-Monty-Python.html (data obrashcheniya: 01.01.2016).

75. You don't know if she's on her period: The View hosts clash over Cara Delevingne's awkward interview. URL: http://www. mirror.co.uk/3am/celebrity-news/you-dont-know-shes-period-6161526 (data obrashcheniya: 01.01.2016).

76. Twitter and the celebrity interview. URL: http://www.tandfonline.com/doi/full/10.1080/19392397.2015.1062641 (data obrashcheniya: 01.01.2016).

77. Taylor Swift Just Clapped Back at Kanye West So Hard During Her Album of the Year Speech. URL: http://www.seventeen. com/celebrity/music/news/a38118/taylor-swift-just-clapped-back-at-kanye-west-so-hard/ (data obrashcheniya: 01.01.2016).

78. GQ Magazine. URL: http://www.gq-magazine.co.uk/style/articles/2013-02/22/labrinth-interview-music-and-stylelondon-fashion-weekend (data obrashcheniya: 30.12.2015).

79. Exclusive Interview with Chingy. URL: http://www.tv.com/news/exclusive-interview-with-chingy-6244/ (data obrashcheniya: 01.01.2016).

80. Brendirovanie. URL: www.brandbook.ru/web/brjendirovanije/ (data obrashcheniya: 01.01.2016).

81. BN Saturday Celebrity Interview: “Clarence Peters \& Don Jazzy Are Really Hot / Controversial Singer Maheeda Dishes on Her 'Sexy Propaganda', Married Life, Raising Her Teenage Daughter \& Much More. URL: http://www.bellanaija.com/2013/10/ bn-saturday-celebrity-interview-clarence-peters-don-jazzy-are-really-hot-controversial-singer-maheeda-dishes-on-hersexy-propaganda-married-life-raising-her-teenage-daughter-much-more/ (data obrashcheniya: 01.01.2016).

82. I love showbiz with every molecule of my being! Dilshad Burman. URL: http://www.sagennext.com/2013/04/26/i-loveshowbiz-with-every-molecule-of-my-being-dilshad-burman/ (data obrashcheniya: 01.01.2016).

83. Dancing with the Stars. Allen Image. URL: http://www.collin.edu/pr_images/magazinePDFs/201301Dancing WithTheStarsAllenImage.pdf (data obrashcheniya: 01.01.2016).

84. Zankovskii A.N., Nartsissova S.Yu. Diskurs v virtual'nom obshchenii: motivatsionno-potrebnostnye i rolevye determinanty // Psikhologiya i psikhotekhnika. 2015. № 6. P. 560-569. DOI: 10.7256/2070-8955.2015.6.15501. 